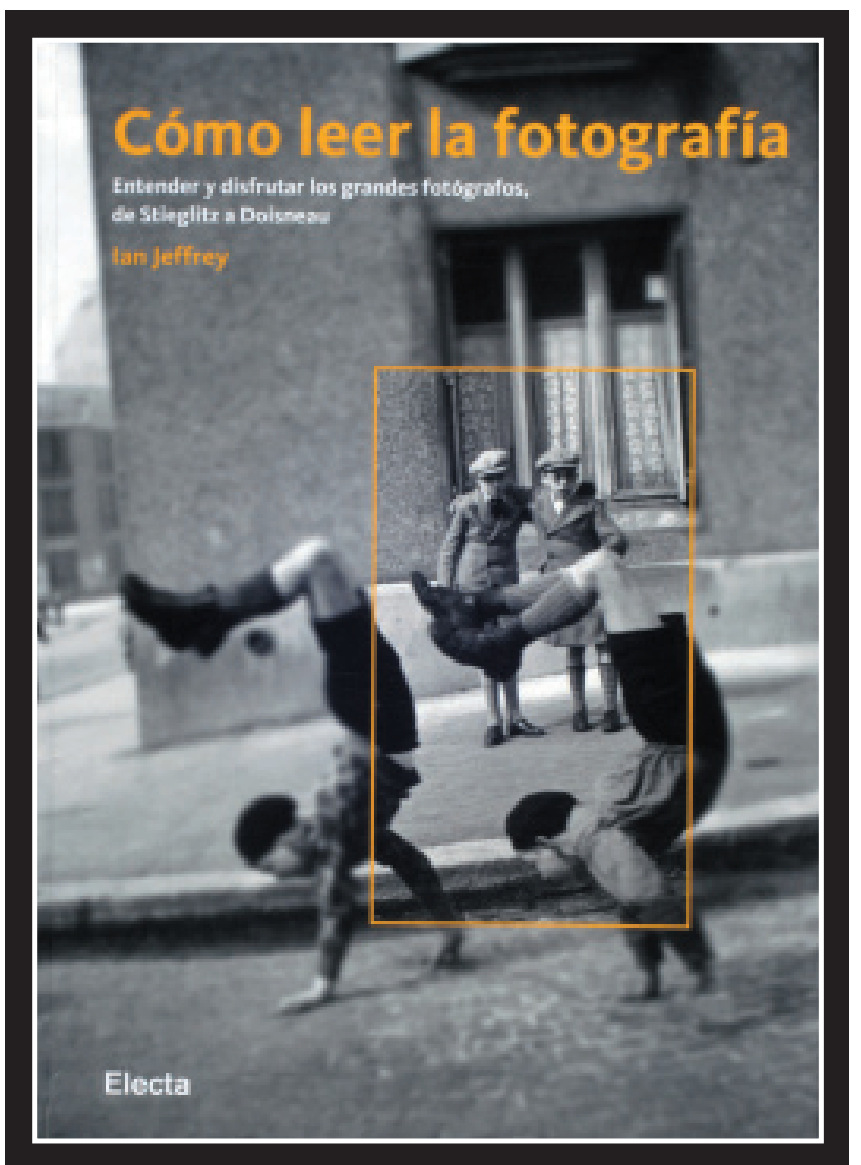

Cómo leer la fotografia - Entender y disfrutar los grandes fotógrafos, de Stieglitz a Doisneau, de Ian Jeffrey. Traducción de Israel Ortega. Barcelona: Editorial Electa, 2009, 383 p. 


\title{
Como analisar e compreender uma fotografia
}

\author{
Adair Felizardo*
}

O livro Cómo leer la fotografía, do escritor, crítico de fotografia e professor da Universidade de Londres, Ian Jeffrey, se traduzido para o português, poderia ter como título Como analisar e compreender uma fotografia, que abrangeria melhor o que o autor pretende com sua obra. De uma forma concisa e brilhante, ele consegue expor todas as nuances interpretativas de uma imagem. E não são simples imagens.

Jeffrey reúne em seu livro nada menos que os principais expoentes do mundo da fotografia, desde os primeiros fotógrafos da década de 40 do século XIX, até a segunda metade do século XX. O livro tem como subtítulo "entender e apreciar os grandes fotógrafos, de Stieglitz a Doisneau", mas também poderia ser subtitulado "de Fenton a Capa", "de Cameron a Cartier-Bresson", tantos são os mestres da fotografia agraciados pelo autor. São mais de 70 fotógrafos apresentados por uma breve e interessante biografia, que merece especial atenção, pois encontramos detalhes da vida pessoal e profissional dos artistas, sua maneira de trabalhar e de se expressar com suas fotografias.

Ex-assistentes são testemunhas de fatos e passagens da vida e obra de seus mestres, como o fotógrafo checo Josef Sudek (1896-1976), que perdeu um braço na Primeira Guerra Mundial, mas com o seu empreendedorismo, determinação e superação, fundou a Sociedade Fotográfica Checa, na década de 20. Jiri Toman, seu ex-assistente, descreve um dos projetos de Sudek, de 1950, quando fez fotografias para o livro Praha Panoramatická, com 284 imagens panorâmicas de

\footnotetext{
* Fotógrafo. Especialista em Fotografia pela Universidade Estadual de Londrina (2000). Professor do Curso de Especialização em Fotografia: Práxis e Discurso Fotográfico na UEL. Pesquisador em história, narrativa e registros audiovisuais.

${ }^{1}$ Tradução livre do original: "Entender y disfrutar los grandes fotógrafos, de Stieglitz a Doisneau"
} 
Praga, publicado em 1959: "Era uma incrível atividade desportiva que começava às nove e meia da manhã e terminava com o pôr do sol. Levávamos três câmeras ou mais, diversos materiais, tripés e uma câmara escura portátil para recarregar os filmes nas câmeras panorâmicas."” (JEFFREY, 2009, p.180).

$\mathrm{O}$ autor pontua apenas algumas fotografias de cada um dos fotógrafos, e às vezes temos duas imagens, às vezes dez, doze. No livro todo, são mais de quatrocentas imagens. Não há uma lógica na escolha da quantidade de fotografias para análise e, em muitos casos, nem certo grau de importância dentro de um contexto histórico ou de ser uma fotografia célebre, das mais conhecidas pelo público. Há situações em que as fotografias são do acaso, momentos furtivos do cotidiano. $\mathrm{O}$ interessante é que Jeffrey destrincha a fotografia em seus mínimos detalhes. Faz uma verdadeira análise estética da imagem, causando, muitas vezes, emoção ao leitor, fazendo-o sentir, além da beleza, sensações, indagações, questionamentos. A forma, o plano, a luz, os grafismos, a composição, a estética propriamente dita, uma aula sobre os pontos de vista e modos de interpretar uma imagem.

Aspectos técnicos, vigentes na época de cada fotógrafo, são revelados no livro. Também há uma contextualização com os movimentos artísticos e políticos aos quais os fotógrafos estavam inseridos e que, de alguma forma, influenciaram seu trabalho.

Além do ótimo trabalho de pesquisa com alguns dos grandes mestres da fotografia mundial, Jeffrey abre um adendo às imagens produzidas nas duas guerras mundiais e ao arquivo fotográfico da Resettlement Administration y Farm Security Administration, agência governamental de seguridade social dos Estados Unidos, criada na década de 30 para erradicar a pobreza no país com políticas de reforma agrária e seguro social. As fotografias do banco de imagens da agência - mais de duzentas

\footnotetext{
2 Tradução livre do original: "'una increíble actividad deportiva' que comenzaba a las nueve y media de la mañana y concluía al ponerse del sol. Llevaban tres cámaras o quizá icluso más, diversos materiales, trípodes y um cuarto oscuro portátil para recargar película en la cámara panorâmica".
} 
mil - são assinadas por nomes como Walker Evans, Theodor Jung, Ben Shahn, Carl Mydans e Dorothea Lange, que dispensam comentários. Entre os fotógrafos citados por Jeffrey sentimos a falta de nomes que mereceriam figurar em sua lista, por sua relevância e contribuição à fotografia mundial, como: Helmut Newton, Sebastião Salgado, Elliot Erwitt, Willian Eugene Smith, Josef Koudelka e outros.

Publicado em 2009, simultaneamente em inglês e espanhol, Cómo leer la fotografía, de finíssimo acabamento e qualidade editorial, é um excelente guia para os amantes das artes, estudantes e professores de fotografia, pensadores da nobre arte de fazer fotografia. 